\title{
UNIVERSITYOF
}

FORWARD

THINKING

WESTMINSTER用

WestminsterResearch

http://www.westminster.ac.uk/westminsterresearch

\section{Why Spontaneity Matters: Rosa Luxemburg and Democracies of Grief}

Tambakaki, P.

This is a copy of the accepted author manuscript of the following article: Tambakaki, P. (2020) Why Spontaneity Matters: Rosa Luxemburg and Democracies of Grief. Philosophy and Social Criticism. Advanced online publication. doi:10.1177/0191453719876978. The final definitive version is available from the publisher Sage at:

\section{https://dx.doi.org/10.1177/0191453719876978}

(C) The Author(s) 2020

The WestminsterResearch online digital archive at the University of Westminster aims to make the research output of the University available to a wider audience. Copyright and Moral Rights remain with the authors and/or copyright owners.

Whilst further distribution of specific materials from within this archive is forbidden, you may freely distribute the URL of WestminsterResearch: ((http://westminsterresearch.wmin.ac.uk/)).

In case of abuse or copyright appearing without permission e-mail repository@westminster.ac.uk 


\section{Why Spontaneity Matters. Rosa Luxemburg and Democracies of Grief}

Spontaneity is a fascinating concept. It frames diverse forms of action, pervades socio-political life and takes on various forms. For all its analytical virtues, however, it is a concept that has failed to have a bearing on any key debates in political theory. A few explanations spring to mind. The first has to do with the impulsive overtones of the concept that, at first level of intuition, are troubling to political theorists that privilege rationalist forms of political activity. Another explanation has to do with its Marxist pedigree that sits uneasily with a liberal political theory unconcerned by questions of political organization (see Levant 2012). Although there are a few exceptions, notably in anarchist and radical thought, they also end up rejecting spontaneity as too short-lived to yield any meaningful sociopolitical transformation.

The present article strikes out in a different direction. It seeks to explain why spontaneity matters. It argues that it matters because spontaneous initiatives deliver a capacity for producing change that it is pressing to probe in the wake of growing discontent with democracies that fail to deliver for the people they are supposed to serve. This article captures this discontent with the idea of "a grieving mood". It proposes that a theoretical orientation that values spontaneity engenders fresh reflection on the politicization and reassurance that short-lived initiatives incite - as they inspire larger movements that improve on democracy as a set of practices and institutions.

To develop this argument, I engage with Rosa Luxemburg's work. I suggest that Luxemburg's various reflections on spontaneity help us to grasp its democratic potential. On the one hand, this is because Luxemburg wrestles with the ways that 
democracies expand through grassroots struggles taken up by the excluded, marginalized and oppressed. As Jon Nixon notes, "to think as a democrat is" for Luxemburg "to acknowledge the agency of the oppressed in the making of history" (2018, viii). On the other hand, it is also because Luxemburg forges a close tie between spontaneity and the popular consciousness that democracies nurture and are nurtured by. By so doing, she gives substance to the concept. She associates spontaneity with self-activity and thus treats it as something separate from the type of self-organization that galvanized her contemporaries - including her own later work on council democracy (see Muldoon 2018).

Understood as a self-acted and therefore conscious initiative, spontaneity leaves a mark on democratic regimes that can be otherwise difficult to discern. It is this mark that I capture with the term "capacity for change" - a capacity that Luxemburg suggests develops in struggle through considered, but nonetheless spontaneous, initiatives that act in a situation. Taking heed of these spontaneous initiatives is significant for political theorists that seek to resist the effects of neoliberalism on contemporary democracies. It is also significant for those theorists that seek to negotiate the loss of affect for democratic institutions and practices. For spontaneous democracy, the name I give to the frame of analysis inspired by Luxemburg's work, taps into the experiences of loss and disaffect that pervade today.

The references to spontaneous democracy, that I develop more fully in the last section of the article, immediately raise questions about the way that I approach Luxemburg's insights into spontaneity. Luxemburg was writing at a particular time (early twentieth century), through a particular Marxist prism into the revolutionary events and debates of her time and with a particular aim in mind, namely the 
socialist transformation of society. Can her context-bound reflections on spontaneous initiatives carry value for the contemporary, rather different, context?

This is a difficult subject to broach if one intends to neither overplay nor understate the value of Luxemburg's reflections for the contemporary context. The former approach that usually brackets out questions of interpretative practice and situated context, ${ }^{1}$ gestures towards perennial problems, solutions and lessons that contemporary activists can begin to derive from Luxemburg's work (see Nixon 2018, 67, 126; Memos 2012). The second approach, that exaggerates the situated nature of her interventions, tends to see little distinctiveness in Luxemburg's work outside its own context. ${ }^{2}$

To stir a middle course between these two positions, one that sees value in Luxemburg's work while registering the situated nature of her insights into spontaneity, I develop a two-step approach. First, I draw forth the potential that Luxemburg sees in spontaneity. Second, I build on this potential - not on Luxemburg's account of spontaneity per se - in order to illuminate how our own loss of affect for democracy might be better negotiated if we begin to think through this potential. The merit of this two-step approach is that it allows me to sketch the deadlock that confronts contemporary liberal democracies without falling back on false analogies between different contexts. If the problem with democratic institutions and practices today is how to elicit their revival in the face of widespread disaffection with the democratic lexicon, then Luxemburg's investment in the potential of spontaneity to deliver something, throws light on one way we might begin to break through this deadlock. It also throws light on a particular aspect of spontaneity, namely, the capacities for change that this hones, that only comes forth when one 
begins to read Luxemburg's reflections alongside the idea of a grieving mood for a troubled democratic practice.

This is where, in the end, the value of Luxemburg's work resides: in her approach, or perhaps more fittingly, her attitude to spontaneity and the orientation that this attitude can inspire in contemporary democracies ${ }^{3}$ In later sections, I explain further how the idea of a spontaneous democracy illuminates this orientation. Before this, I start by exploring some reasons for the marginalization of spontaneity in political theory. Then I move on to discuss Luxemburg's account of spontaneity, canvassing the tangible benefits that this yields to the idea of spontaneous democracy.

\section{Spontaneity in Political Theory}

As a first approach, spontaneity designates an impulsive and short-lived reaction to an event or situation. Spontaneous reactions are often assumed to be unplanned, in the sense of lacking directions from a central committee, and unpredictable. For this reason they are feared or celebrated depending on whether they slide toward chaotic gatherings that threaten public order or creative events that effectively publicize the injustices that citizens have spontaneously reacted to. Examples of the kind of spontaneous reactions that I have in mind here are many and diverse: from protests against Executive Order 13769 in 2017 to Ferguson in 2014 following the death of Michael Brown, Istanbul in 2007 when mass crowds gathered in the streets of the city to grieve the assassination of activist Hrant Dink and Belgium in 1996 when spontaneous protests erupted throughout the country against the justice system and its management of major crime cases (Gambino 2017; Gunce Demirhisar 2016). 
No doubt, such examples raise some questions that are worth considering. The first is whether reactions that are tagged as spontaneous are ever impulsive and unplanned. ${ }^{4}$ The second question is whether such assumingly unplanned reactions elicit changes that become incorporated in institutions, associations and civic customs. The section shows that political theorists, in the tradition of radical democracy in particular, confidently recognize that impulsive and unplanned reactions to exclusions, oppressions and injustices constitute part and parcel of the democratic tradition (Stears 2010). What they are less confident about is whether such reactions, that are inherently short-lived, have any tangible effects on society. This remarkably consensual dismissal of spontaneity is important to take note of because it serves to ground the discussion in subsequent sections, particularly the guiding assumption of the article that spontaneity matters. It also helps to foreground that the reason why it matters is because it delivers something, namely the capacity to produce change in a context where discontent with democratic institutions and practices is rife. For large segments of political theory, however, spontaneity is ineffective in bringing about socio-political change.

For example, for Ernesto Laclau (2005) and Jodi Dean (2016) organization and party leadership are key to taking forward the kind of popular demands for equality that will initiate political change. Popular movements, argues Laclau, do not spontaneously come together to challenge unresponsive governments $(2005,108)$. To construct a "vague solidarity" among such diverse and largely heterogeneous movements, more than spontaneity is needed for Laclau, namely, the construction of a negative unity that mobilizes the difference and frustration that issues from unmet popular demands $(2005,103)$. Without such constructed unity - or in other words, without any organization and coordinating work - transformative politics is out of the 
question. Along similar lines, Jodi Dean doubts the transformative scope of spontaneous movements (Dean 2016). Worried, specifically, about political change in the wake of a communicative capitalism that co-opts acts of resistance, Dean finds in what she refers to as crowd events traces of a political subjectification necessary for the emergence of an egalitarian alternative to capitalist democracy. Crowd events, argues Dean, are spontaneous - impulsive and intense - moments of collective assembling full of political potential. They intensify feelings of belonging and, in so doing, they discharge equality. For this equality to endure, however, parties are indispensable. Without the organized struggle that parties provide, spontaneity is for Dean - much like for Laclau - exciting but ineffective in inciting socio-political change.

For other theorists, less sanguine than Laclau and Dean about the prospects of transformative politics, spontaneous activities 'fail' (if this is still the right word) because they are not meant to endure in the first place. They are momentary movements that are inherently fragile - vulnerable, that is, to the continuous institutionalization of unequal social powers (Wolin 1996, 31-45). This second position finds expression in the work of Sheldon Wolin who stresses the episodic dimension of contemporary democratic practice, but doubts its capacity to challenge in any serious way the bureaucracies, hierarchies and power networks that permeate democratic institutions (Wolin 1996 and 2006). Of course, fugitive democracy interrupts and disrupts institutional politics according to Wolin. It serves as reminder that the (excluded) people, who collectively emerge to act upon this politics, are its basis. But episodic movements are not in any way transgressive. They cannot have effects other than dislocatory, for they always retreat. They might "educate and 
energize particularisms" (Wolin 2006, 11) but they fall short of anything more creative $^{5}$

To be sure, there are theorists, such as Michael Hardt and Antonio Negri, who appreciate the transformative potential of spontaneous politics, arguing that this delivers a kind of self-organization that eventually invents non sovereign institutions $(2017,39)$. .The difference with the discussion that the subsequent sections develop, is that Hardt and Negri raise expectations of institutional rupture. Interested, primarily, in the steps to the institution of an alternative, more just order, they probe the capacities and, indeed, potential of movements to resist and innovate (2017, 232). In so doing, they associate spontaneity with a type of revolutionary capacity that is missing from the analysis of this article - where spontaneous initiatives only foster experiences that are affective enough to vivify democratic practice within contemporary liberal democracy.

From my perspective, then, spontaneous initiatives are also generative but the kind of capacity they generate is not one that helps to initiate an alternative democratic order based on the organization of the common. It is, instead, the capacity to incite another experience of this democracy. The discussion of Black

Lives Matter in the last section substantiates this point. Here suffice to note that temporalities other than those that define slow work of repair and fast work of revolution show enough potential to vivify democratic institutions and practices. Rosa Luxemburg's grasp of such temporal politics helps us to begin to think through this potential. The next section explains why and how.

\section{Spontaneity through the lens of Rosa Luxemburg}

The task of this section is to outline Rosa Luxemburg's account of spontaneity with the aim of drawing out and formalizing those features of the concept that will 
ground my discussion in the next two sections. Luxemburg's account is of value to this discussion for two reasons. First, it resists reducing spontaneity to an impulsive reaction that requires organization to deliver change (as Laclau and Dean would have it). It also resists reducing spontaneity to a form of self-organization that evades all need for party representation (as Hardt and Negri do). Instead, Luxemburg gives spontaneity a content that, as we will see, is closer to Wolin's momentary politics. But she insists, pace Wolin, that spontaneous activity carries significant sociopolitical implications for the survival of democratic institutions and practices. It delivers the training and unity necessary for the transformation from unequal to socialist democracy.

This emphasis on change or, in other words, Luxemburg's insistence on the potential of short-lived activity to deliver something, is precisely what I find useful for my discussion as it contributes to a fuller understanding of the place of spontaneity in a democracy. But this understanding, I want to note, does not seamlessly flow from Luxemburg's own texts. What follows is, thus, my own development of the content that Luxemburg inscribes to spontaneity as much as it is a presentation of her own transparent arguments about its impact on democracy. I take the licence for this reading from Luxemburg's prescient defence of democratic rights and institutions that summons attention to the popular dimension that is often elided in Marxist accounts of workerist and revolutionary politics.

To draw out more clearly this uniqueness of Luxemburg's work, that I suggest here resides in the insights she generates for democracy, one needs to begin by taking note that spontaneity for Luxemburg captures any popular or collective initiative, such as the 1905 Russian mass strikes, that originates "from specific local accidental causes, without plan and undesignedly" (2008, 142). Spontaneous 
initiatives of the type characterize revolutionary - not demonstration - strikes according to Luxemburg. Demonstration strikes "exhibit the greatest party discipline" (2008, 142). By contrast, revolutionary strikes that Luxemburg associates with spontaneity are the expression, if not culmination, of a period of class struggle aiming at the socialist transformation of society. For this reason, "they cannot be called at will" $(2008,147)$. "A mass strike born of pure discipline and enthusiasm", explains Luxemburg, "will, at best, merely play the role of an episode, of a symptom of the fighting mood of the working class" $(2008,147)$ - it will not on its own bring socialism. The struggle for socialism draws then on the force of spontaneous initiatives but it also draws, as will shortly see, on a certain "class awakening" (2008, $129)$ - first prepared and subsequently sustained by political parties $(2008,149)$. As a result, it is closely tied to the struggle for democracy - if by democracy one understands not just grassroots action but also, much like Luxemburg, an institutional regime that attends to popular demands (see 2008, 88).

Seen, moreover, as an inclusive regime, democracy depends on socialism for its survival. The socialist labour movement, stresses Luxemburg, "is the only support for that which is not the goal of socialist movement - democracy. [...] democracy can have no other support" $(2008,88)$. The close connection that Luxemburg thus establishes between struggles for socialist transformation and democracy — indicate that spontaneity is through her lens a more nuanced term than it appears at first sight. The remaining of the section examines this further, starting with the notion of struggle that as we have just seen Luxemburg lodges at the centre of her account of spontaneity.

The idea of struggle designates the series of actions that seek to challenge and eventually transform bourgeois democracy $(2008,64-65$ and 130-131). This is 
an important first point to take heed of because it elucidates that the kind of activity that qualifies as spontaneous according to Luxemburg encompasses but is not reduced to isolated incidents or short lived reactions to events. Understood as part of a wider struggle, spontaneous activity is multifarious. It includes issue-specific protests - aiming to reform the early twentieth century German democracy that Luxemburg writes about; mass strikes - that challenge absolutism as in the case of 1900's Russia; and daily acts of agitation that set apace the socialist transformation of society.

Another way to approach this emphasis on struggle is to view it as part of a wider process of consciousness formation. "From Luxemburg's perspective", explains Jon Nixon, "collective action springs from a critical understanding .. [that while] based on the experience of exploitation must be mediated through a process of critical consciousness whereby one's experience is understood within a broader social and economic totality" $(2018,89)$. Without this reference to socio-economic totality and the broader process of forming a critical agency, spontaneous activity makes little sense for Luxemburg. A look at The Mass Strike - the essay where she develops her account of spontaneity - explains why.

The mass strikes of 1905 are neither strictly economic nor political phenomena according to Luxemburg. They are protests that weld together experiences of oppression, rooted in economic relations, with the critical awareness of these experiences as it emerges in and through ongoing struggle. This critical awareness, that I will later discuss in terms of self-activity, implies that spontaneity for Luxemburg captures, first, the way that the exploited and the oppressed act when they have come to grips with the totality of their condition: in a prepared but, nonetheless, undirected manner. Second, spontaneity captures the popular, bottom- 
up, and inevitably, self-acted dimension of the protests. Third, and as a result of the above spontaneous activities carry the potential for new forms of organization, including that of a council democracy. They are, therefore, both important catalysts for change - helping to raise the critical consciousness that will initiate such change and manifestations of preparation and awakening. Let us examine these three features of spontaneity in more detail.

The undirected dimension of spontaneous activity, that hems in questions of leadership and organization, comes first. What does it mean to say that spontaneous activity is undirected? The term captures, as we have seen, the idea of a class awakening - a process of subjectification. This awakening, inspired and directed by political parties according to Luxemburg, makes spontaneous activity appear somewhat less spontaneous - if by spontaneity we understand only an impulsive reaction to an event. While impulsiveness is certainly one marker of spontaneity, this does not make it any less directed or prepared. Indeed, spontaneous activity for Luxemburg is prepared and directed - that is, planted by parties and channelled through (extra)parliamentary struggle - towards the path of socialist transformation. As Luxemburg explains in The Mass Strike, sudden and impromptu ruptures are "not just 'made", "decided at random, or propagated" $(2008,117-118)$. They are the fruits of ongoing work done inside and outside social democratic parties.

This emphasis on parties, or in other words leadership, must not go amiss for it fuels two further readings of Luxemburg's approach to spontaneity that disagree on its relation with organization. On the first reading, popular among scholars who heighten the significance that Luxemburg gives to the pace of revolutionary struggle, spontaneity captures a tactic decided and controlled by leadership (Gluckstein 2012; Geras 1973). It is not an underlying dimension of the struggle that, as I propose 
here, issues from ongoing engagement in (extra)parliamentary activities. It is, instead, the time-limited method to accelerating the revolution. On the second reading, dominant among critics of Luxemburg's work, spontaneity is the antithesis of organization and, as a result, an altogether ineffective means to attaining sociopolitical change - a goal that, for the same critics, calls for strong leadership as well as for discipline and control (Wolfe 1961).

Unable to grasp spontaneity as something other than a response to revolutionary situations, the two readings construct a binary that restricts reflection to the effectiveness of centralized leadership in such situations - a restriction that resurfaces today in debates about horizontality and verticality (see Prentoulis and Thomassen 2013). For Luxemburg, however, centralism is only "a tendency" that is not suitable for social democracies $(2010,89)$. The spirit of such democracies requires: "the co-ordination and unification of the movement and not its rigid submission to a set of regulations. [For] it is not the letter, but the living spirit carried into the organisation by the membership that decides the value of this or that organisational form" $(2010,93)$.

In other words, organization, understood as a process of co-ordination and unification, emerges out of struggle - paving the way for political rights and conditions for parliamentarianism where it is missing as in the case of 1900s Russia (2008, 114). Where democratic parliamentarianism is not missing, as in Germany where Luxemburg is based, organization prepares and sustains the struggle. It frames the common experience of the masses (2010, 233); educates them $(2008,130)$ and feeds into wider desires for change $(2008,162)$. In so doing, organized struggle - in the weak way I have defined it here - fosters and nurtures 
self-activity. This is, as I have already mentioned, another main feature of Luxemburg's account of spontaneity.

The idea here is the following: if political struggle - that is, struggle coordinated by parties and other organs such as trade unions - prepares the masses for politics, by educating and unifying them as a collectivity that is aware of its disadvantaged position in society; then this collectivity is in a position to act on its own initiative. This is especially the case in revolutionary situations according to Luxemburg, where: "initiative and direction do not consist in issuing commands [...], but in the most adroit adaptability to the given situation, and the closest possible contact with the mood of the masses .. [In such situations] spontaneity plays such a predominant part [...] because revolutions do not allow anyone to play the schoolmaster with them" $(2008,148)$.

Self-activity thus suggests in this context a readiness to act in the situation. This captures more than the preparedness to act that I discussed above. It is also conceptually distinct from the idea that the workers who act spontaneously organize in a leaderless, grassroots, way. Strictly speaking, self-activity captures an initiative and, therefore, something more nuanced than the capability for collective decisiontaking that is hemmed in the related notion of self-organization.

This initiative encompasses impromptu events or incidents, for the working people might suddenly take to the streets to demand better conditions; but is not exhausted by such events or incidents. It is not, in other words, synonymous with an unruly politics, even though the impromptu or unscripted nature of the events that spring from deep inequalities and grievances often do acquire a momentum of their own - as was the case with the Russian mass strikes that Luxemburg writes about. But this impromptu nature far from being counter-intuitive captures something that is 
germane to Luxemburg's rendering of spontaneous activities, namely, their ordinariness. While extraordinary events might occur, these will always be part of the type of activity that I have so far laid down as ongoing and self-acted, organized and multifarious.

Another way to grasp this ordinariness of the spontaneous activity that Luxemburg argues for, in my reading, is to stress its popular and, inevitably, democratic dimension. With an unbridled faith in the masses, Luxemburg makes amply clear, throughout her work, that no popular democracy is worth defending if it marginalizes and excludes the masses - the only collectivity with real interest in democratic institutions. In this respect, she distinguishes between a bourgeois democracy that abandons the masses by enacting reforms in the interests of capital and a socialist democracy that attends to popular demands and needs $(2008,58$ 64). Socialist democracy, she argues, is precisely that which popular struggles that are ongoing and self-acted must strive to bring about. This is: "not something which begins only in the promised land [..] It does not come as some sort of Christmas present [..] Socialist democracy begins simultaneously with the beginning of the destruction of class rule and the construction of socialism. [It concerns] the manner of applying democracy, not its elimination" (2010, 235).

It follows that democratic institutions and rights - at least where these are in place - offer fertile ground for the advent of socialist democracy. To see why one must note that the move from bourgeois to socialist democracy becomes possible only if and when the masses are at the helm of the process. It is, then, to the support of this task that democratic institutions come to be indispensable by "rendering the conquest of power [by the people] both necessary and possible" (Luxemburg 2008, 93). On the one hand, democratic institutions create and sustain the political forms 
that serve the people "as fulcrums in its task of transforming bourgeois society" (Luxemburg 2008, 93). On the other hand, the very "exercise of democratic rights, this struggle for democracy" enables the people (and particularly the proletariat) to become aware of its leading role in the socialist transformation of society (Luxemburg, 2008, 93).

No doubt, Luxemburg's discussion of socialism and her emphasis on a socialist - inclusive and popular - democracy finds a strong echo in contemporary calls for a left populism that distances itself from the stagnation and elitism of institutional politics. At the same time, Luxemburg's consistent focus on the popular dimension of democracy, evident in her calls to extend the class struggle to the masses foreshadows the post-Marxist shift away from classes to the people as the collective subject of politics (see Luxemburg 2008, 158-159). It also foreshadows contemporary demands for a more egalitarian politics - as these percolate through much of today's political theory. But there is a difference. Whereas many political theorists voice serious reservations about whether contemporary democratic institutions can change, ${ }^{6}$ Luxemburg's work fuels confidence in the self-correcting dimension of institutional democracies: "the living movement of the masses, their unending pressure" $(2010,229)$. "The leadership has failed', argues Luxemburg and she continues: "But a new leadership can and must be created by the masses and from the masses. The masses are the crucial factor" $(2010,267)$.

This emphasis on the masses begs one final, crucial, question. If democracies change through popular pressure; and if to exert such pressure is a form of experience that draws on spontaneous activities that are ongoing and multifarious; then perhaps, democracy, understood here as a system that both encourages popular pressure and is vulnerable to such pressure, makes ruptures superfluous. ${ }^{7}$ 
Luxemburg takes up this question in Reform or Revolution where she argues - pace Bernstein - that to oppose revolution to democracy, let alone to settle with a reformist approach to questions of democratic change, is to abandon the struggle for socialist transformation. The materiality of social relations, a capitalist state and persistent forms of domination, make apparent the need not just for change but for revolutionary change in particular. Yet revolution appears dispensable when it is seen as "action of feeling", a "rapid method of progress" and a "spontaneous force" (Luxemburg 2008, 89). But revolution is not "one happy act" for Luxemburg (2008, 95). It relies on preparation and ongoing work, including efforts to secure institutional reforms. Understood, therefore, as the part of the struggle that keeps the conquest of political power a vivid goal, revolution delivers a socialist democracy in tandem with - not independently from - reforms. Later in the article, I will suggest that a perspective that rethinks the importance of spontaneity for democracy recognizes that what spontaneity delivers today is a capacity to (eventually) strengthen democratic practice. But here it suffices to note that transformative politics for Luxemburg remains a possibility in a democracy as long as spontaneous activities harbour and channel desires for both revolution and reform.

Alex Levant makes a similar point. Interested in "spontaneity as a more complex phenomenon than it appears in orthodox Marxism", he sets out to examine its impact on society by using the work of E.P. Thompson, Antonio Gramsci and Walter Benjamin $(2012,369)$. Levant argues that spontaneity far from being the unconsidered or unconscious response to economic conditions (as orthodox Marxists would have it) is a reaction that "ebbs and flows" depending on particular social conditions and the way the people who experience these conditions interpret their impact on their socio-political life (Levant 2012, 369). Spontaneous resistance 
thus draws on popular consensus and carries an innate political significance for those who engage in it, as it contains the seeds for significant socio-political transformation. While spontaneity, therefore, still designates a reaction for Levant and not an initiative as I propose here- it is one that is considered and contextdependent. For this reason, spontaneity constitutes, on Levant's reading of Luxemburg's account, the most radical way in which the people can transform their conditions and achieve self-emancipation.

With the transformative potential of spontaneity now in full view, the way opens for using Luxemburg's account of spontaneity as an anchor enabling another orientation to democratic practice. The next section takes a decisive step to this direction by building on the benefits of spontaneity that issue from Luxemburg's work. It argues that prominent among these benefits is the politicization and reassurance that self-acted initiatives bring to contemporary democracies of grief where experiences of loss and disaffect predominate.

\section{Spontaneity Reconsidered}

The previous section concluded by bringing focus to the transformative potential of the spontaneous activity that Luxemburg makes the case for. The task of this section is to expand on this focus by beginning to outline the ways that spontaneity bears on democratic practice - thus building on the potential of spontaneity that Luxemburg outlines. To this end, it is useful to gather together those features that make Luxemburg's approach to spontaneity worth considering.

The first three features that stand out is that spontaneous activity is for Luxemburg undirected but nonetheless prepared, popularly led and indeterminate in terms of its socio-political effects. While it originates in work done inside and 
outside the party system; it is not action decided or controlled by leadership. Instead, spontaneous activity is unscripted and impromptu. It puts the people to the centre of the political scene, bringing visibility to their discontent with the fraught economic conditions that they find themselves in. This visibility is promising for Luxemburg. It initiates socio-political transformations that lay the groundwork for another more democratic world. On this reading, spontaneity emerges less as a reaction that orchestrated by leadership - offers a steppingstone to another order and more as a considered initiative that enfolds, and thus prefigures, the very democratic character of the socialist order.

Understood, furthermore, as an initiative, spontaneity strips of overtones of unconsciousness. This is especially important because it shows that it is possible to avoid reducing spontaneity either to a passing stage in the emergence of socialism or to a time-limited tactic for producing socio-political change. As Luxemburg underscores, spontaneous initiatives 'spiral' and 'pulsate' (2008, 141). They are 'living organisms' that are difficult to control by steering to one or another direction (Luxemburg 2010, 101). This difficulty does not, nonetheless, indicate that spontaneous initiatives are of a rare, even exceptional, nature. They are ordinary, intricate, moments of the everyday and ongoing struggle for socialist democracy. For this reason the study of spontaneous initiatives yields benefits to theorists troubled by the limits of the democratic lexicon.

To grasp these benefits, one needs to reflect further on the potential of spontaneous initiatives to deliver democratic change. While Luxemburg certainly recognized this potential, she did not, understandably, expand on the ways that this might be achieved. It is the task of this section to initiate such discussion, arguing that this is both urgent and necessary. It is urgent because growing distrust and loss 
of affect for contemporary democracy make pressing the need to re-examine our assumptions about spontaneity. It is necessary because in the age of social media initiatives that are spontaneous are not just the norm, but also a potent force. They bring visibility to the socio-political structures (governmental or otherwise) that they impulsively confront and, in so doing, they draw considerable attention to the people gathered around a cause.

Zeynep Tufekci (2017) stresses that attention is an invaluable resource for any movement that seeks to expose a situation, action or event by showing its wider impact on society. Attention offers the movement an affordance that is significant if its initiative is to strike a chord with segments of the society unaware of the reasons for the action. But attention is not an automatic resource according to Tufekci. Powerful actors might intentionally or unintentionally deny it and most movements must, for this reason, strive to secure it. Spontaneous initiatives differ from most movements in this respect. If one considers how they unexpectedly intrude into everyday life, then it becomes reasonable to propose, in a step further from Tufekci, that such initiatives attract attention more readily than controlled actions that are designed and planned to resolve an issue.

What distinguishes spontaneous initiatives from such actions is precisely their sudden or ad hoc nature that almost immediately sparks curiosity. This curiosity indexes less a concern with the scale or reasons of the initiative and more an interest in the popular gathering, as if the initiative was empty of reasons or cause. Of course, interest in the form (more than in the cause) of spontaneous initiatives their apparent self-referentiality - is not on its own sufficient to explain the force of spontaneity as a tool of analysis. After all, other forms of action, such as protests organized by social movements, might spontaneously mobilize and generate interest 
in their form rather than cause - even more so in today's networked societies. Therefore, it is necessary to expand on the benefits that spontaneous initiatives yield to contemporary democratic practice. Politicization stands out from such benefits, endowing spontaneous initiatives with further force.

Politicization is an ever present dimension of spontaneity. If Hannah Arendt (1958) is correct that politics is the realm of appearance, it is by appearing in the public scene, by subjectifying, that the people come to act and, thus, politicize. This is not the type of politicization that other forms of socio-political action exploit to bring focus to their cause. It is not pre-existent - formed either prior to or in the course of articulating the popular demand. ${ }^{8}$ It is more protean than this, more indeterminate, because it is not yet funnelled towards a specific goal, for spontaneous initiatives sometimes precede and others serve as groundwork for the emergence of these goals. Thus when such goals do emerge, spontaneity has delivered a politicization that up to that point was non-existent. Or to put the same point differently, spontaneous initiatives give rise to demands and organization after their emergence - as we will see in more detail in the next section when I discuss Black Lives Matter. This renders them a particularly useful resource for today's democracies that have lost their capacities for generating renewal inasmuch as popular support.

To explain the significance of spontaneous initiatives for contemporary democratic practice, it is worth pausing to consider some of their limits and the way these have impacted on levels of popular support. Democracies, it has been argued, fail to deliver for the people they are supposed to serve (see Gilens and Page 2014). Influenced by the designs and powers of the oligoi, they fashion policies that undermine, and often ignore, popular demands for better living conditions and 
standards. The inequalities that these policies harness must not be brushed aside. They seriously threaten democratic institutions and practices.

They also elude the way to strengthen these, and this is crucial for my discussion. If Wendy Brown (2015) is correct that years of neoliberal governmentality have both normalized inequalities through processes of economization and killed homo politicus - the rights-bearing subject who is in a position to resist economic normalizations; then the task of reviving democracy is more difficult to fathom than political parties and social movements usually presume. This difficulty is compounded by the impact that sustained attacks on democratic principles have had on economies of desire for more democracy. Attacks on universal suffrage - the voters who lack capacities for judgment (see Brennan 2016); representation - that distorts popular wills (Sitrin and Azzellini 2014) and institutions - that systematically favour corporations and the wealthy (see Gilens and Page 2014) have all done a good job at lowering expectations of change in and through democratic institutions. Alarmingly, they have also undermined affect for democratic practice.

It is in this alarming context that spontaneous initiatives make a difference. What is especially instructive about such initiatives is that they presume little about the impact they might have on broader society. This is important because it taps into lowered expectations of meaningful change in democratic regimes. But spontaneous initiatives do not altogether abandon aspirations to change. Instead, they limit such aspirations to actions on a situation and, in so doing, they offer reassurance that things can be otherwise - not that things must or will be otherwise as homo politicus is recovered, only that politicization is in sight and, thus, intuitions for change have spawned. This reassurance is, to my mind, vital today that it is difficult to find a way 
to strengthen democratic practice - without underestimating either the inversions ${ }^{9}$ that this has undergone or the loss of affect that such inversions have wrought.

Yet if we agree that there are benefits to spontaneity more broadly, the question becomes whether these benefits accrue as a result of Luxemburg's account of spontaneity in particular. I want to argue that Luxemburg's account is especially prescient because it allows us to see spontaneity as something other than a passing reaction to an event. Understood as an initiative and, therefore, as one part of an ongoing struggle for socialism, spontaneity leaves a mark on democratic practice that it is difficult to discern without Luxemburg's fuller exploration of the concept. But Luxemburg's exploration must be further unpacked if her contribution to my discussion is to be made more explicit. The suggestion that I therefore want to make, as a next step, is that Luxemburg's rendition of spontaneity as an initiative becomes separated from connotations of socialist self-organization that she encumbers it with in her later work (after the creation of the Spartacus League in 1914) - not that it must be separated from such references, only that these must be pushed to the background for my argument to come through. Otherwise I fall back on overplaying the value of her work, outlining solutions that, from the perspective of this article and the emphasis it places on the loss of affect for democratic practice, compromize the specificities of the contemporary context

If the need for this move is thus conceded, the space opens to see that what spontaneity now specifically delivers today is the politicization and reassurance that I earlier identified as vital for the contemporary context. For this reason, spontaneity must spark the interest of more political theorists - especially those that, deeply worried about the prospects of democratic practice in the face of neoliberalism, seek to revive the democratic lexicon. 
Of course, the question remains whether there is enough affect left for democratic practice to even consider the revival of its lexicon. But the bite can be taken out of this question if one starts from the assumption that affect for democracy is, as we have seen, already at a low ebb. With this assumption as starting point, focus shifts to the kind of revival that is at issue. This is, to be clear, a revival in the weak sense of the term. It entails neither a reworking of democratic identifications nor the recovery of homo politicus. It is more in the nature of an orientation toward democracy that, while it reconciles with the discontent over the inequalities that this harnesses, it uses this discontent as springboard for another approach to the subject of change that could, in the end, bring back confidence in this democracy.

This orientation is, to be sure, inspired by Luxemburg's account of spontaneity. It is not, however, the lesson that one derives from her work. As I explained earlier in the article, there is no reservoir of lessons, answers or solutions to transplant to our present. This means, indeed, that homo politicus might not, in the end, be recuperated. But far from serving as cause of despair this possibility makes the shift of attention to spontaneity compelling. If homo politicus cannot be recovered right now, then spontaneous initiatives that pressure and catalyze efforts to 'other' our world are not anymore a small thing. They make a difference in that they open less charted but no less far-reaching pathways to socio-political change. The next section captures one such pathway with the idea of spontaneous democracy. It argues that an account of democratic practice that recognizes and values spontaneity as selfactivity is in better position to capture the ways in which spontaneous initiatives, rife today, create and hone capacities for producing democratic change. 


\section{Spontaneous Democracy}

The previous section concluded by suggesting that the shift to spontaneity is compelling today that democratic societies have lost their capacities for generating renewal and popular support. If this is correct, then we need a frame of analysis that enables us to come to terms with the place of spontaneity in such changed sociopolitical context. Spontaneous democracy captures such a frame. This is important because it allows us, first, to build on the potential of Luxemburg's account of spontaneity while illuminating the specificities of the contemporary content - the fact that spontaneous initiatives are as will shortly see already around us to notice. On the other hand, it allows us to place the effects of such initiatives - the larger movements they inspire - within a framework that, if taken seriously, can revive affect for democracy.

Thus spontaneous democracy, far from being a theory that offers a systematic exposition of key democratic features or a counsel on how to improve political life, only outlines a frame of thinking, a vantage point of the present. This frame helps us to grasp the possibilities of change hemmed in the operations of today's societies that, while ubiquitous, our analytical capacities have not yet caught up with. As other frames of analysis, spontaneous democracy is selective. It offers a snapshot of prevailing trends and a partial reflection on change that captures only those tendencies that are, to my mind, in line with the fraught times that we find ourselves in - where inequalities grow rampant and populism reigns supreme. This reflection leans heavily on Luxemburg's rendition of spontaneity, cashing in on its promises. It moves beyond Luxemburg's rendition by investing in a vocabulary that is, without doubt, alien to her times and work. 
The aim of this vocabulary is to rework the tie between spontaneity and democracy by showing that, contrary to what most political theorists argue, spontaneity creates and hones capacities for producing democratic change. Understood as the horizon that limits and enables thinking on forms of socio-political equality, democratic practice expands through initiatives that are impromptu but, nonetheless, conscious. It is not synonymous with such initiatives - as is the case, for example, with Wolin's fugitive democracy (1996) - and this is an important first point to note about spontaneous democracy. Had the latter been synonymous with the former, there would have been little need to invest in another vocabulary that reworks the tie between spontaneity and democracy. Therefore, the second point to note about spontaneous democracy is that the contact it creates between spontaneity and democracy lays the basis for a rendition of change that, in line with Luxemburg's insights into spontaneity, is not parsed into either revolutionary or reformist.

To anticipate in a nutshell this rendition, I want to draw out the ideas of generative action, expressivity and grief that lie at the centre of the vocabulary that spontaneous democracy reworks. On the back of the assumption that a widespread sense of discontent incites temporary, or at least addressable, affective states such as lamentation, mourning and grief - states that are, in other words, widely probed by political theorists for their mobilizing effects; ${ }^{10}$ I suggest, in a leap forward, that these non-existential, potentially temporary, experiences of loss gesture toward types of mobilization that are impromptu and ad hoc. They gesture, in other words, to forms of political expression that are spontaneous if by spontaneity we understand, much like Luxemburg, an impromptu but, crucially, conscious, form of action that carries repercussions despite its popular (and thus self-referential) short-lived nature. 
The claim that I thus want to defend in the rest of the section is that spontaneous initiatives are generative processes that inspire the emergence of larger movements and the creation of capacities that have the potential to deliver, if not reignite, popular affect for democratic practice.

To be precise, then: an account of democratic practice inclined to recognize spontaneous initiatives is one that reconciles with the (valence of) negativity inherent in our socio-political world - the widespread disaffect and distrust of democratic governments, that, as we have seen, fail to deliver for the people they are supposed to serve. The result of this reconciliation with negativity is an attitude that cashes in on the negative mood that pervades it. Moods, explains Nina Trcka (2017), are ubiquitous. They are also invariably shared. "Moods are not inner mental states that a person has 'inside' herself, but they are ways of being situated in the world" (Trcka $2017,1648)$. They capture "the (atmospheric) qualities of the situations in which we find ourselves" and they are, as a result, always embodied and intersubjective (Trcka 2017, 1648).

Moods are embodied because they arise in plural sites of appearance - in expressive spaces - where participants influence and are influenced by bodily expressions such as gestures, eye contact, slogans etc. They are intersubjective because they rely on the contribution and, ultimately, affective interchange between various participants. For this reason, moods are "attuned forms of embodied coexistence or pre-intentional forms of interaffectivity" (Trcka 2017, 1650). As Trcka puts it: The embodied emotional experience of others is not perceived in a detached manner; it is feelingly perceived - we may feel touched by it or even deeply affected, it involves us [especially] if we partake in it [...]. To share thus a mood means to contribute to a mood and thereby to create an affective interdependence between 
persons. The affective interdependence is the vehicle of the collective mood (2017, $1655,1659)$.

If this is correct, then it is useful, as a next step, to approach moods as vectors of negative emotions. They register experiences of loss, injuries and deep-seated discontent with socio-economic dispossession. Grief, that I earlier discussed in passing, is an especially apt emotion to capture these experiences. Understood as a response to loss according to Freudian psychoanalysis (see Freud 2005, 203-207), a feeling of pain that lessens with the passing of time, grief is not a surprising state to focus on if we take seriously the idea that popular affect for democratic practice is, in the wake of growing inequalities, running out of steam. Of course, grief is not the only emotion that registers an experience of dispossession. Anger is a similar emotion in this sense (see Mclvor 2012, 421). However, I want to insist on grief because, unlike anger, it offers a way to negotiate the loss of affect for democracy that I find especially fitting for contemporary conditions where alternative objects of attachment have not yet been discerned. Grief, then, does not index a form of universal suffering constitutive of politics. It captures a mood and, in so doing, it finetunes with a perspective on democracy that recognizes the significance of spontaneous initiatives that negotiate a difficult situation.

The underlying idea behind this fine-tuning is straightforward. Given that grief onsets the mourning process that negotiates the loss (of homo politicus), it funnels through mobilizations that muster ephemeral, but no less determined, interruptions of socio-political orders. What precisely tethers these mobilizations to spontaneity is the tension between grief as an embodied and inter-subjective mood that energizes action and the limits that this action confronts once it bursts into the scene by drawing back on (the pain that comes with) grief. In other words, the claim I want to 
advance here is that while grieving moods are, as most political theorists would affirm, especially mobilizing. They are also, much like any other mood, self-limiting. They last only as long as the participants partake in the mood. Then they dispel, but this does not diminish their socio-political effects. Another way to express the same point is to say that grief, understood as a mood, summons more attention to the gathering of the people, to their expressive space" (Trcka 2017, 1657) than to the grieving subject who creates this space. But this does not mean that there is no subject, for collective moods encourage the emergence of an expressive subjectivity.

Expressive subjectivity captures two main ideas. The first is the obvious one of expression - a gesture of discontent with the way that democratic regimes operate. The second is that of the activist subject that emerges as a result of this expression. Subjects who act on their own initiative are what Tufekci (2017) often refers to as networked subjects. They are apolitical citizens who engage in networked activities and, in the process, politicize by participating in the shared space of the grieving mood. For grief is, as we have seen, a strong enough emotional state to inspire politicization. One example that, to my mind, captures this politicization issues from Ferguson in August 2014. The stunned crowds that gathered in the streets of Ferguson for two weeks following the death of Michael Brown certainly included activists. They also received support from organizations such as MORE and Organization for Black Struggle (see Kauffman 2017, 178-179). But they were neither the direct product of such organizing nor purely impulsive responses of grief - especially when one considers the role of social media and, indeed, the hashtag BlackLivesMatter in publicizing the gatherings (Garza and Kauffman 2015). Instead, they were sites of politicization funnelling expressions of 
grief and discontent toward the formation of local organizations such as Millennial Activists United or Lost Voices (see Kauffman 2017, 182) .

Spontaneous democracy thus frames a particular type of political action that I want to capture as 'generative'. Generative action describes the effect of spontaneous initiatives on democratic practice - the idea that such initiatives produce organization after they have dispersed. It can be placed within a wider literature that studies (and contrasts) forms of organization in contemporary activist practices. Questions of change are also of primary concern in this literature, turning on the alliance, and at times opposition, between horizontal and vertical forms of organization. ${ }^{11}$ Both these forms are, through the lens of spontaneous democracy, secondary. For what is primary is that spontaneous initiatives generate organization. They do not capture the form of horizontal or vertical coordination that leads to change. In other words, they do not capture strategies or tactics of change. Instead, they make an opening to change. It is precisely this opening to organization that I now want to argue has far reaching effects on society.

To grasp these effects, it is useful to consider the way that the Black Lives Matter movement gathered momentum after the events in Ferguson. Black Lives Matter, explains L.A. Kauffman, started as "the focal point for an urgent online conversation about the state of black America and grew into a grassroots national movement" $(2017,173)$. Originally, then, a hashtag that in 2013 created the space to share grief, Black Lives Matter emerged in the aftermath of Ferguson (particularly Ferguson October in 2014), as an especially effective organization for drawing attention to police killings, and in so doing, to wider narratives about the manner of policing in US communities, the criminal justice system and racism (Kauffman 2017, 174; Tufekci 2017, 205-209; Graza and Kauffman 2015). Of course, the point here is 
not that the chapter-based, member-led organization that is now Black Lives Matter is the seamless product of the Ferguson protests in 2014 . The point is also not that Black Lives Matter exemplifies a novel - horizontal - experiment in self-organization. Instead, the claim I want to advance is that an organization as effective as Black Lives Matter grew out of experiences of grief and loss, social media activization and ad hoc gatherings - in other words, out of spontaneous but for that matter no less considered initiatives.

This leads to the conclusion that the effects of spontaneous initiatives on democracy are around us to notice. We have, nonetheless, failed to trace some of these effects back to spontaneous initiatives on the assumption that these are either rare, exceptional or ineffective. In the contemporary context, however, where seeds of spontaneity inhere in any gathering engineered by social media, it is significant that we begin to do so. For spontaneity, an unlikely frame of reflection for political theorists, creates and hones capacities for resistance. While it is not itself a form of resistance, it is the springboard for a re-orientation to democratic practice that cashes in the politicizations that grieving moods generate. Spontaneous democracy, then, the name I gave to this orientation, captures the effects of spontaneity on democracy: the larger movements it inspires and the political capacities it hones. Without attention to these capacities and how they are developed, it is difficult to negotiate the experience of dispossession and loss of affect for democratic practice that pervades today. Without Rosa Luxemburg helping us to take heed of these capacities as capacities that develop in struggle, in other words as considered initiatives that act in and transform a situation, it is difficult to see that spontaneity delivers for democratic practice a much needed activization. 


\section{Conclusion}

The article engaged with Rosa Luxemburg's account of spontaneity arguing that this offers a range of resources to rethink the benefits that spontaneous initiatives yield to the contemporary context. Specific in this context is, as I argued, a collective mood of grief for a democracy lost. Spontaneous democracy taps into this grief and offers a temporary relief for the anxieties that this engenders. It readily garners attention to the initiative, it politicizes what has been considered up to this point as apolitical and it generates action that might have far reaching effects on our socio-political imaginaries. Spontaneous democracy thus creates and hones capacities that vivify this democracy.

\section{Endnotes:}

${ }^{1}$ On this issue see Skinner (1969, 50-52).

${ }^{2}$ For example, Paul Frölich (2010) ties Luxemburg's reflections with early twentieth century discussions of historical materialism about the stages of revolutionary struggle (see Lukács 1968; Lenin 1987) - thus failing to see any distinctiveness in her account of spontaneity within Marxism, let alone outside it.

${ }^{3}$ I am here influenced by Jeffrey Green's argument in "Political Theory as Both Philosophy and History: A Defense Against Methodological Militancy" (2015).

${ }^{4}$ For instance, see the case of Rosa Parks. Despite her actions appearing spontaneous they were the effect of much planning, organization and training. See Tufekci $(2017,62)$.

${ }^{5}$ This is George Kateb's criticism of Wolin's account of fugitive democracy (2001, 40). 
${ }^{6}$ Among others see Brown (2015) and Dean (2016).

${ }^{7}$ Agonistic theorists such as Bonnie Honig and Chantal Mouffe convincingly develop this idea. See Wenman (2013).

8 This is what Laclau, for example, suggests in On Populist Reason (2005).

${ }^{9}$ Crouch (2004) offers a good discussion of these inversions.

10 See Honig (2013), Butler (2004); Mclvor (2012); Stow (2017).

${ }^{11}$ For a good overview of this debate see Kioupkiolis (2018).

\section{References}

Arendt, Hannah. 1958. The Human Condition. Chicago: University of Chicago Press. Brennan, Jason. 2016. Against Democracy. Princeton, NJ: Princeton University Press.

Brown, Wendy. 2015. Undoing the Demos: Neoliberalism's Stealth Revolution. New York: Zone Books.

Butler, Judith. 2004. Precarious Life: The Powers of Mourning and Violence. London and New York: Verso.

Crouch, Colin. 2004. Post-Democracy. Cambridge: Polity Press.

Dean, Jodi. 2016. Crowds and Party. London and New York: Verso.

Freud, Sigmund. (1917) 2005. Mourning and Melancholia. London: Penguin.

Frölich, Paul. 2010. Rosa Luxemburg. Chicago, Ill: Haymarket Books.

Gambino, Laura et al. 2017. "Thousands Protest Against Trump's Travel Ban in Cities and Airports Nationwide". Guardian, January 29, 2017. https://www.theguardian.com/us-news/2017/jan/29/protest-trump-travel-banmuslims-airports (accessed September 10, 2018).

Garza, Alicia, and L.A. Kauffman. 2015. "A Love Note to Our Folks: Alicia Garza on the Organizing of =BlackLivesMatter." n+1 Magazine, January 20, 2015. https://nplusonemag.com/online-only/online-only/a-love-note-to-our-folks/ (accessed September 20, 2018).

Geras, Norman. 1973. "Rosa Luxemburg: Barbarism and the Collapse of Capitalism." New Left Review 82: 17-37.

Gilens, Martin, and Benjamin I. Page. 2014. "Testing Theories of American Politics: Elites, Interest Groups and Average Citizens." Perspectives on Politics. 12(3): 564-581.

Gluckstein, Donny. 2012. "Standing the Test of Time. Reform or Revolution." Critique 40(3): 389-403.

Green, Jeffrey. 2015. "Political Theory as Both Philosophy and History: A Defense Against Methodological Militancy." Annual Review of Political Science 18: 425441.

Gunce Demirhisar, Denise.2016. "Emotion and Protest in Turkey. What Happened on 19 January 2017?”. Open Democracy, January 28, 2016. 
https://www.opendemocracy.net/deniz-g-nce-demirhisar/emotion-and-protest-inturkey-what-happened-on-19-january-2007 (accessed September 10, 2018).

Hardt, Michael, and Antonio Negri. 2017. Assembly. New York: Oxford University Press.

Honig, Bonnie. 2013. Antigone Interrupted. Cambridge: Cambridge University Press Kateb, George. 2001. "Wolin as a Critic of Democracy." In Democracy and Vision:

Sheldon Wolin and the Vicissitudes of the Political, edited by William E. Connolly and Aryeh Botwinick, 39-57. Princeton, NJ: Princeton University Press.

Kauffman, L.A. 2017. Direct Action: Protest and the Reinvention of American Radicalism. London and New York: Verso.

Kioupkiolis, Alexandros. 2018. "Movements Post-hegemony: How Contemporary Collective Action Transforms Hegemonic Politics." Social Movement Studies 17(1): 99-112.

Laclau, Ernesto. 2005. On Populist Reason. London: Verso.

Laclau, Ernesto, and Chantal Mouffe. 2001. Hegemony and Socialist Strategy. London: Verso.

Le Bon, Gustave. (1896) 2014. The Crowd. Chicago, III: Aristeus Books.

Lenin, Vladimir. (1902) 1987. "What is to be done?". In Essential Works of Lenin, edited by Henry M. Christman, 53-175. New York: Dover Publications.

Levant, Alex. 2012. "Rethinking Spontaneity Beyond Classical Marxism: Re-reading Luxemburg through Benjamin, Gramsci and Thompson." Critique 40(3): 367387.

Lukács, Georg. 1968. History and Class Consciousness: Studies in Marxist Dialectics, Georg Lukács. Cambridge, MA: MIT Press.

Luxemburg, Rosa. 2008. The Essential Rosa Luxemburg. In The Essential Rosa Luxemburg, edited by Helen C. Scott. Chicago, Illinois: Heymarket Books.

Luxemburg, Rosa. 2010. Socialism or Barbarism: The Selected Writings of Rosa Luxemburg. In Socialism or Barbarism: The Selected Writings of Rosa Luxemburg, edited by Paul Le Blanc and Helen C. Scott. London: Pluto Press.

Mclvor, David. 2012. "Bringing Ourselves to Grief: Judith Butler and the Politics of Mourning." Political Theory 40(4): 409-436.

Memos, Christos. 2012. "Crisis of Theory, Subversive Praxis and Dialectical Contradictions: Notes on Luxemburg and the Anti-Capitalist Movement." Critique 40(3): 405-421.

Muldoon, James. 2018. Council Democracy: Towards a Democratic Socialist Politics. New York: Routledge.

Nixon, Jon. 2018. Rosa Luxemburg and the Struggle for Democratic Renewal London: Pluto Press.

Prentoulis, Marina, and Lasse Thomassen. 2013. "Political Theory in the Square: Protest, Representation and Subjectification." Contemporary Political Theory 12(3):166-184.

Sitrin, Marina, and Dario Azzellini. 2014. They Can't Represent Us: Reinventing Democracy from Greece to Occupy. London and New York: Verso.

Skinner, Quentin. 1969. "Meaning and Understanding in the History of Ideas.". History and Theory 8(1): 3-53.

Stears, Marc. 2010. Demanding Democracy: American Radicals in Search of a New Politics. Princeton and Oxford: Princeton University Press.

Stow, Simon. 2017. American Mourning: Tragedy, Democracy, Resilience. 
Cambridge and New York: Cambridge University Press..

Trcka, Nina. 2017. "Collecive Moods. A Contribution to the Phenomenology and Interpersonality of Shared Affectivity." Philosophia 45: 1647-1662.

Tufekci, Zeynep. 2017. Twitter and Tear Gas: The Power and Fragility of Networked Protest. New Haven and London: Yale University Press.

Wenman, Mark. 2013. Agonistic Democracy. Cambridge: Cambridge University Press.

Wolfe, Bertram D. 1961. "Rosa Luxemburg and V.I. Lenin: The Opposite Poles of Revolutionary Socialism." The Antioch Review 21(2): 209-226.

Wolin, Sheldon. 1996. "Fugitive Democracy." In Democracy and Difference:

Contesting the Boundaries of the Political, edited by Seyla Benhabib, 31-45.

Princeton, NJ: Princeton University Press.

Wolin, Sheldon. 2006. "Agitated Times." Parallax 11(4): 2-11. 